\title{
DO MĀORI RIGHTS RACIALLY DISCRIMINATE AGAINST NON MĀORI?
}

\author{
Claire Charters*
}

Claire Charters argues that the claim that Māori rights discriminate against non-Māori needs to be tested to a greater extent than it has been in both political and academic circles to date, not least because of its importance to the type of nation New Zealand is and seeks to be. She illustrates that from a contextual, comparative and theoretical standpoint Māori rights do not discriminate against non-Māori and to suggest that they do so will only increase Māori's detachment from the New Zealand polity.

\section{INTRODUCTION}

The suggestion that Māori rights discrminate against non-Māori New Zealanders is one that has attracted political and public attention as well as attention from legal academics. At heart, Brash's Orewa "One Law for All" speech expressed this sentiment, and the resulting up-surge in support for the National Party in 2004 indicated that a good number of New Zealanders share this view. ${ }^{1}$ Similarly, the New Zealand Government argued against provisions of the UN Declaration on the Rights of Indigenous Peoples on the grounds that they discriminated against non-Indigenous. ${ }^{2}$ More recently, esteemed professor Philip Joseph suggested that the Māori seats constitute a discriminatory privilege upsetting the electoral equality of "one person, one vote, one value." ${ }^{3}$ In addition to the

* Ngati Whakaue, Nga Puhi, Tuwharetoa and Tainui. Senior Lecturer, Law Faculty, Victoria University of Wellington. My sincere thanks to Richard Boast, Claudia Geiringer, Kirsty Gover, Dean Knight, Paul McHugh, Nicole Roughan and the anonymous reviewer for comments on a draft of this paper. As always, all views, errors and omissions remain my own.

1 Don Brash "Nationhood" (Address to the Orewa Rotary Club, Orewa, 27 January 2004).

2 See, for example, Statement by HE Ambassador Rosemary Banks on behalf of New Zealand, Australia, the United States and Canada to the UN General Assembly Third Committee Item 64(a) The Declaration on the Rights of Indigenous Peoples (United Nations, New York, 16 October 2006) www.mfat.govt.nz/Media-andpublications/Media/MFAT-speeches (accessed 3 March 2009).

3 Philip Joseph "Te Papa Address" (Wellington, 5 February 2009). 
Māori seats, Treaty of Waitangi settlements, the potential that Māori could have had property rights in the foreshore and seabed and educational scholarships designated for Māori appear to fuel the perception that Māori receive benefits that discriminate against non-Māori.

I argue that the claim that Māori rights discriminate needs to be tested to a greater extent than it has been in political circles and by some academics; it is a plea for more sophisticated debate in the light of the legal, political and social factors that suggest that it would in fact cause injustice, an inequality, not to recognise Māori rights. While the racial discrimination claim, as it has been expressed in the public domain, notes a difference between rights enjoyed by Māori and non-Māori New Zealanders, ${ }^{4}$ it glosses over nuanced, contextual, comparative and international understandings of Indigenous peoples' rights, racial discrimination and equality. It also ignores scholarship on the justifications for the recognition of Indigenous peoples' rights based on the equality premise.

It is important to eruditely address the issue of Māori rights and racial discrimination because it is fundamental to the type of nation we are, and want to be. Equality is one of those overarching values to which most liberal democracies strive and is associated with the rule of law. ${ }^{5}$ Moreover, inequality within a state lessens the willingness of marginalised groups to be a part of the state and the legitimacy of the state's claim to authority and jurisdiction over such groups. ${ }^{6}$ As importantly, Māori rights relate to the mortar of our constitutional and political edifice, which, at least

4 The instinctive appeal of equating difference with discrimination is encapsulated in this quote from Jeremy Waldron, "[o]ur belief in the rule of law commits us to the principle that the law should be the same for everyone: one law for all and no exceptions. It would be quite repugnant if there were one law for the rich and another for the poor, one law for black Americans and another for whites. Formally at least, we repudiate all such classifications, and to the extent that they still exist in our law or in the way our law is administered, we believe they disfigure, or at least pose grave difficulties for, our commitment to the rule of law ideal." Jeremy Waldron "One Law For All? The Logic of Cultural Accommodation" 59 Wash \& Lee L Rev 3, 3. Mason Durie points out that New Zealand's adherence to the view that equality requires identical treatment is an emanation of their social history and, in particular, the welfare state era between 1935 until at least 1984. He states: the philosophy of the Welfare State was based on the premise that 'Jack was as good as his master', one person as good as the next, and both should have the same opportunities and privileges. It was a distinctly New Zealand reaction towards the snobbery, social layering and demarcations based on wealth, and a clear signal that New Zealanders - particularly Labour Party supporters - were ready to bury an lingering sentiment for upper class privilege and lower class compliance. Residual rights associated with a sense of privileged status or inherent superiority were to receive no social or legislative recognition though by the same token neither were the rich to be denied a share of the Welfare State pie. The family benefit for example was paid to all mothers with young children, regardless of economic circumstances or need. Mason Durie "The Treaty of Waitangi, Equality of Citizenship and Indigeneity" (Address to the Human Rights Commission Workshop on the Relationship between the Treaty of Waitangi and Human Rights, Wellington, 8 July 2003).

5 See Nicole Roughan "Te Tiriti and the Constitution: Rethinking Citizenship, Justice, Equality and Democracy" (2005) 3 NZJPIL 285.

6 Eskridge Jnr "The Circumstances of Politics and the Application of Statute" (2000) 100 Colum L Rev 582. 
rhetorically, is premised on supposed Māori consent to kawanatanga (governance) in return for protection of their tino rangatiratanga (chieftainship) over their taonga under the Treaty of Waitangi.

I make three closely-related points in this paper. First, a contextual analysis suggests that it is Māori who were, and are, discriminated against, not non-Māori. Taking a number of factors into account, detailed below, one must be careful before alleging that Māori rights discriminate on racial grounds. Second, the view that Indigenous peoples' rights discriminate racially goes against the wisdom of jurisdictions against which we compare ourselves favourably, and that of the international legal order. While it can always be argued that the circumstances in New Zealand are different, we ought to at least evaluate the merits of the justifications for these alternative views and explain why and how the circumstances in New Zealand warrant different assessments of equality. An insular and uncritical view risks arrogance and undeveloped, unconvincing conclusions. Finally, contemporary and predominantly liberal thinking about Indigenous peoples' rights, principally from Canada, suggests that equality requires the recognition of Indigenous peoples' rights.

The focus of this paper is the claim that the Māori seats discriminate against non-Māori, as expressed by Joseph and mentioned above. I suggest that unique Māori political rights are neither racially based nor discriminatory. However, many of the arguments made here support and justify Māori rights generally, be they property, Treaty, culturally or need-based even if, ultimately, the equality, or inequality, of each type of right is deserving of specific analysis, and some kinds of rights may more intuitively attract the claim of racial discrimination than others. ${ }^{7}$

\section{A CONTEXTUAL ANALYSIS}

Māori in Aotearoa live within a constitutional and legal structure that is, and remains, foreign to them in its genesis and quality. New Zealand's parliamentary system is derived from England. The lingua franca of political and legal discourse is English. Our legal system is almost completely blind to Māori rangatiratanga, guaranteed in the Treaty, and customary law unless, which is infrequent, Parliament has agreed to its application. Parliamentary sovereignty does not accommodate any competing sovereign, let alone pluralistic sovereignties: power vests in Parliament, alone. In other words, Māori live under a constitutional and legal system that is unknown to their legal and cultural tradition, and in lands, which at most 169 years ago, iwi exercised sovereignty, as recognised by the British Crown in the 1835 Declaration of Independence.

My instinct is that New Zealanders are, as a whole, deeply attached to the value of equality. It is something of which we should be proud generally. What we need to recognise, however, is we have been hearing in the public domain an interpretation of equality that requires the exact same treatment of all. It is what is suggested by Brash's words, "one law for all". This view of equality is blind to the very real differences that permeate our society and the individuals within it: differences,

7 See, generally, Benedict Kingsbury "Competing Conceptual Approaches to Indigenous Group Issues in New Zealand" (2002) 52 Uni of Toronto LJ 101. 
such as cultural attachments, which we cannot change at will or by choice. The one-law-for-all view also assumes that we all have the same equality of opportunity. This formalistic view of equality, without respect for difference, fails to recognise that treating all people the same under the law can de facto aggravate rather than remedy inequalities facing non-dominant groups such as Māori. ${ }^{8}$ This is especially true in circumstances where the legal system reflects the cultural and other biases of the non-Indigenous majority, being a democracy, and is sourced in the majority's historical constitutional ideology,

As a corollary to the above point, the one-law-for-all view is culturally biased, favouring Western conceptions of "the law". We see this in comments by Stephan Franks when he was the Justice spokesperson for the ACT Party in 2004. He implies that the "one law" should be the law of the state, not customary law, unless the customary law conforms to and is accepted by the state legal system. Indeed, Franks does not think that customary law is worthy of the title "law" in and of itself because it is not easily ascertainable and cannot be "looked up". As such it is "antithetical to the rule of law." He states that "the word 'law' is devalued when serious scholars allow the term to be applied to unwritten customs, etiquette, practices and claims". ${ }^{9}$

The one-law-for-all view is also assimilationist. Members of the previous Labour Government also, albeit indirectly, made equality-based arguments to reject recognition of customary law into New Zealand's legal system. Trevor Mallard, the then Race Relations Minister, made a speech about powhiri in schools. He criticised both the length of powhiri and that "women are relegated to a supporting role." ${ }^{10} \mathrm{He}$ went on to say "[w]hile it is important to respect traditions and places of mana whenua, it is important that this is not at the expense of the ideals and traditions of New Zealand education and its commitment to equality for all." ${ }^{11}$ The then Prime Minister, Helen Clark, supported his views. ${ }^{12}$ Underlying this is the idea that customary law is only tolerable if it conforms to the values reflected in the mainstream legal system. So, Māori customary law must assimilate if it is to be deemed appropriate. However, there can be little overall equality where the law of one group, in this case that of Māori, is portrayed as inferior and is expected to conform to the standards prescribed by another legal system. This is especially true when the mainstream legal system fails to

8 For more on this issue, see Andrew Sharp Justice and the Maori: The Philosophy and Practice of Maori Claims in New Zealand Political Argument Since the 1970s (2 ed, Oxford University Press, 1997).

9 Stephen Franks "Going Native: What Indigeneity Should Look Like in the Morning" (Address to the Australasian Law Reform Agencies Conference, Wellington, 15 April 2004).

10 Stuart Dye and Jon Stokes "Mallard hits at 'sexist' Maori ritual" (25 September 2004, New Zealand Herald, Auckland).

11 Ibid.

12 "PM Supports Shorter Powhiri" (30 September 2004) NZ City http://home.nzcity.co.nz/news/ (accessed 15 February 2009). 
understand the context and logic of the indigenous customary legal system, such as the justifications for different roles for men and women. ${ }^{13}$

Aotearoa's legal system operates as a democracy in which the majority rules. Māori are usually in the minority when the majority considers their unique rights, as the Foreshore and Seabed Act 2004 (FSA) illustrates, enabling the majority to suppress Māori rights. ${ }^{14}$ Within the mainstream parties, even those MPs who identify as Māori and/or have been elected to a Māori seat, have voted against Māori interests, as our system enables party leaders to whip them into a party-consistent position in line with the views of the majority of the party's constituency. ${ }^{15}$ It is perhaps not surprising, then, that New Zealand has passed legislation to make Māori spiritual leaders illegal, under the Tohunga Suppression Act 1907, to lock up Māori who protested against Government and its decrees, ${ }^{16}$ or to extinguish Māori customary and land rights under the FSA.

Many Māori have been and are at the bottom of almost all socio-economic indicia since records started, and remain some of the poorest, hungriest, least-educated and most locked-up peoples in this country. This alone suggests that explanation is required before allegations of racial discrimination are made about the recognition of rights that could assist in the alleviation of this socio-economic disparity.

The Treaty of Waitangi, which is etched into our collective psyche and has at least rhetorical value as our founding constitutional document, ${ }^{17}$ guarantees Māori rangatiratanga, a form of political power, over their taonga (tangible and intangible treasures), including their lands. The point is an old one but can be expressed thus: how can New Zealand's legal structure fail to give effect these Treaty rights, which purportedly found our Constitution and the distribution of power within it, without calling into question the robustness of our constitutional structure and its legitimacy more generally? ${ }^{18}$

13 See Claire Charters "Maori and BORA: Fundamental Issues" [2003] NZLJ 459 and "Maori, Beware the Bill of Rights Act" [2003] NZLJ 401.

14 See William Connolly "The Liberal Image of the Nation" in Duncan Ivison, Paul Patton and Will Sanders (eds) Political Theory and the Rights of Indigenous Peoples (Cambridge University Press, Cambridge, 2000) 188 and cited in Roughan above n 5 297. As Roughan notes, "[w]hile such majoritarian rule lies at the heart of democracy, it is necessary to move beyond a model where the majority need not take into any account of the interests of minorities".

15 "Responding to Waldron's Defence of Legislatures: Why Parliament Cannot Protect Rights in Hard Cases" (2006) 4 NZ Law Rev 621.

16 Suppression of Rebellion Act 1863.

17 As described by Sir Robin Cooke, as he then was, in "Fundamentals" [1988] NZLJ 158.

18 F M (Jock) Brookfield Waitangi and Indigenous Rights Revolution, Law and Legitimation (Auckland University Press, Auckland, 1999). 
While Joseph might argue that the Treaty does not require Māori electoral seats, focusing on the equality principle implicit in Article $3,{ }^{19}$ he fails to mention the tino rangatiratanga guarantee in Article 2. It is a glaring omission, ${ }^{20}$ confounded by his 2008 Report on the Māori seats for the Business Roundtable, where he argues that the Treaty principle of active protection does not require unique Māori political rights. ${ }^{21} \mathrm{He}$ omits the point that the principles of the Treaty can function to weaken the Treaty's explicit textual guarantees to Māori.

True, Article 3 of the Treaty can be read to guarantee equality between citizens - Māori and non-Māori. However, Joseph's assessment is imperfect in that he assumes that "special" provision for Māori political influence results in inequality. As alluded to above, we need to balance up unique measures such as the Māori seats with the fact that the broader political system is institutionally biased against Māori in that it is majoritarian and non-Māori in design, inherited and has facilitated the loss of Māori land and sovereignty.

Moreover, the Māori seats constitute a model for political influence that fits within New Zealand's parliamentary system, not a Māori-based one. While they might not be the best model to provide for guaranteed Māori political influence, they constitute a mechanism that has a certain pedigree given the length of time they have been in place and the country's familiarity with them. ${ }^{22}$ Indeed, it is at least arguable that a constitutional convention has developed whereby they cannot be abolished except with Māori consent. ${ }^{23}$ Evidence of such a convention can be built around the decision not to abolish the seats when MMP was introduced and, also, historical attempts to guarantee Māori representation in Parliament, some of which are noted in Joseph's paper, including attempts to secure Māori chiefs' representation in both houses of Parliament. ${ }^{24}$

As Geiringer points out, the Royal Commission on Electoral Reform, in recommending the abolition of the Māori seats, ${ }^{25}$ did so not because it thought it was inappropriate to guarantee Māori representation but, instead, because "separate representation was ineffective in securing Māori an equitable share of political power." ${ }^{26}$ It also "identified a need for additional protections for Māori

19 Note, also, the point that citizenship in Article 3 ought not be determined solely from an Anglo perspective and discussion of that argument in Nicole Roughan, above $\mathrm{n} 5$.

20 For a discussion of the importance of rangatiratanga and conceptions of citizenship see Roughan above $n 5$.

21 Philip A Joseph Te Oranga o te Iwi Maori: A Study of Maori Economic and Social Progress: The Maori Seats in Parliament (NZ Business Roundtable, 2008).

22 Waitangi Tribunal Wai 413: Maori Electoral Option Report 7 WTR (Brookers, Wellington, 1994).

23 I am grateful to Richard Boast for this point.

24 Joseph, above n 21 .

25 Report of the Royal Commission on the Electoral System "Towards a Better Democracy" (1986) AJHR H3.

26 Claudia Geiringer "Reading English in Context" [2003] NZLJ 239, 239. 
representation", even in the MMP environment, and noted the special constitutional status of Māori with Treaty and minority rights deserving of protection and recognition. ${ }^{27}$

Next, there is something unsettling, jarring even, about allegations that Māori rights discriminate as soon as Māori, after almost a century and a half of political under-representation, loss of land, Treaty breaches and so on, appear to achieve anything close to electoral parity with non-Māori. As Joseph points out, the percentage of Māori MPs in Parliament was slightly more than the percentage of Māori in the population post the 2005 elections. Even assuming that those Māori were elected and sought to pursue a "Māori" agenda, which many do not (as the Labour Māori MPs illustrated during the passage of the FSA and mentioned above), it must be remembered that that is a relatively recent turn of events. For the previous 150-odd years, Māori were mostly underrepresented in Parliament - in early days because the Māori seats represented much larger electorates than the non-designated seats and Māori could only enrol in the Māori electoral roll. Why are the Māori seats questioned as racially discriminatory, coupled with calls for their abolition, as soon as Māori achieve some sort of electoral parity? Why was the 150-odd-year underrepresentation of Māori not considered discriminatory? Could the Māori seats now be conceptualised either as a unique right or even as a special measure required to reverse the longterm effects of a century and a half of under-representation and the failure to recognise Indigenous peoples' entitlements to self-rule, especially given that Māori remain politically non-dominant? ${ }^{28}$ Moreover, we see that where Māori participation in elections is not guaranteed, in many local councils, Māori do not achieve anything like electoral parity. ${ }^{29}$

A similar point can be made about Māori property rights. Why is it, after Māori have lost $95 \%$ of their lands, in part because of colonial land policy, do we hear the view that it is discriminatory to recognise Māori property interests, including customary rights, in the foreshore and seabed? We protect non-Māori property interests; why not Māori property interests?

Can non-Māori legitimately claim to be the victims of racial discrimination when Māori political, property or cultural rights are recognised? For example, do non-Māori really feel discriminated against because there are not reserved seats for which only non-Māori, the majority,

27 Ibid, 240.

28 As Bennett notes of the impact of historical injustice, "[t]he injustice continues, just as it continues when someone unjustly takes a farmer's plow: She cannot work her fields as she ordinarily would, and she continues to feel the effects of the injustice until her plow is returned." Mark Bennett "'Indigeneity' as SelfDetermination" (2005) Indigenous L J 71, 83. See, also, Ivison comments on the continuing impact of historical injustice in Duncan Ivison Postcolonial Liberlism (Cambridge University Press, Cambridge, 2002) 100 .

29 Te Puni Kokiri (Ministry for Maori Development) Whaiwahi ki nga Poti a-rohe (Participate in Local Elections) (Wellington, July 2007) www.localcouncils.govt.nz/lgip.nsf/Files/PDF/\$file/LocalGovtFSLO.pdf (accessed 3 March 2009). 
can vote when, given the percentage of Māori compared to non-Māori in the population, they will almost always dominate the unspecified seats? I am not convinced that the impact of the Māori seats on the majority non-Māori population is anything close to a type of injustice against which our constitutional system should protect, especially when Māori representation is only now reaching levels proportionate to their population percentage. Indeed, the use of the term "racial discrimination" against non-Māori could be seen as belittling to those groups who have suffered the genuine and severe injuries associated with discrimination.

While two wrongs do not make a right, we must also appreciate that absolute equality in democratic process is pragmatically difficult to achieve in any event. ${ }^{30}$ The value of one's vote is rarely exactly equal to others in practice. Gerrymandering, for example, can function to weaken or increase the relative value of one's vote. In this context, we must also bear in mind that the average number of voters in the Māori electorates is currently larger than that in the general electorates, upsetting the one vote, one value mantra. ${ }^{31}$

We would also do well to take into account Paul McHugh's paper on race and Māori, highlighting, as it does, that Treaty jurisprudence in New Zealand is not based on the categorisation of Māori as a racial grouping but, instead, as made up of political tribal units, generally iwi. ${ }^{32}$ The Treaty was not signed with Māori, it was signed by iwi/tribal representatives on behalf of iwi/tribal groups. Thus, McHugh highlights that Treaty or other rights that vest in Māori are not based on race but instead on the status of iwi as unique political groupings. On a legal view, rights do not vest in Māori because Māori are a racial grouping but because they are made up of political units indigenous to this land and with pre-colonisation sovereignty over Aotearoa. He writes: ${ }^{33}$

... race has nothing to do with the Treaty of Waitangi or the principles accredited to it. Why, one asks, does an MP or any politician want to characterise as an issue of race a constitutional document that does not purport to be founded on that basis?

As the distinction in the Treaty rights vesting in Māori and not in non-Māori, which are expressed in our contemporary environment in the Māori seats or customary property rights, is not based on race, it thus is not a distinction that the law should perceive of as racial discrimination. McHugh's view is similar to that found in the United States' jurisprudence on American Indian rights, discussed below. It is a shame, and contrary to practice, then, when Māori are perceived of,

30 I am grateful to Dean Knight for drawing my attention to the points in this paragraph.

31 Elections New Zealand Electoral Populations and Projected Population Variations www.elections.org.nz/mapping/report/10_populations.html (accessed 4 March 2009).

32 Paul McHugh "Treaty Principles: Constitutional Relations Inside a Conservative Jurisprudence" (2008) 39 VUWLR 39.

33 Ibid, 43. 
in papers such as Joseph's, as a monolithic racial grouping, leading to the conclusion that rights for Māori alone are "race based".

Of course, the problem with the characterisation of iwi as political and not racial groupings is that it becomes difficult to claim, then, that measures detrimentally targeting Māori as a group constitute racial discrimination and should, therefore, attract the law's censure, such as the FSA. There are a few comments to be made here. First, as is the principal point in the paper, each claim of discrimination needs to an analysed in the light of its context; sensitive judgment is required as hard and fast rules are difficult. Were, say, Māori required by law to sit at the back of the bus and nonMāori were not, the context might suggest that this is the type of distinction that the law should respond to and prohibit, as perhaps it should also a requirement that non-Māori sit at the back of the bus. The detrimental impact of the allegedly discriminatory measure in question needs to be assessed. Related to this point is the stance taken in the US that negatively-impacting discrimination against American Indians is prohibited under the doctrine of guardianship. In this way, positive treatment of American Indians is not perceived under law as racially-based, but instead uniquely and politically based, and detrimental different treatment of American Indians is also legally prohibited.

Second, if a law treats Māori as a monolithic racial grouping and not as composite of political groupings, for example by expressly abolishing all Māori property interests, rather than the property interests of specific individual iwi, we might interpret that as a legal distinction based on race; as the distinction appears not to be premised on Māori as political units. It could, then, in such circumstances be viewed as a racial distinction and attract censure.

Third, if Māori are not a racial grouping, they may certainly be conceived of as an indigenous grouping. It seems normatively inconsistent, and unjust, to permit negative distinctions based on indigenous descent but to prohibit those based on racial descent.

McHugh also highlights that inequality inherent in historical conceptions of race, and the grouping of peoples into racial categories. ${ }^{34}$ It reflects a Eurocentric ideology that has functioned to justify the domination of some groups over others, rather than prevent it. The perception of other races being inferior - "the noble savage" - justified the subordination of them through colonisation.

\section{COMPARATIVE PERSPECTIVES}

Moving on to comparative jurisprudence, Canada and the United States have made legal and policy choices to insulate Indigenous peoples' political, Treaty, customary and aboriginal rights from assessments of their racially discriminatory effect. One could well draw the conclusion from this that US and Canadian law and policy does not perceive of Indigenous peoples' rights as making, from a qualitative perspective, a racial distinction or, even if so, not one that the legal system,

34 Ibid, 39. 
normatively, should prohibit. This suggests that the recognition of Indigenous peoples' rights are perceived of, juridically, as unique, or sui generis, in those states and are justified even if they inhere only in some groups in society.

In the United States, American Indian nations retain inherent sovereignty over their territories, some of which, such as the Navajo's, are on large land masses crossing over the territory of the individual states. ${ }^{35}$ This means that the American Indian nations exercise jurisdiction over their territories and peoples. The individual states do not have any inherent authority over American Indian lands. While Congress can, and has, exercised its plenary power to take away some of that power in some areas eg, in criminal law, the federal government operates a policy of recognising tribal self-determination. Moreover, even when federal governments exercise their plenary power, they often provide the American Indian nations with the authority to implement the legislation, for example, the Indian Civil Rights Act or the Safe Drinking Water Act. ${ }^{36}$ Political autonomy in the form of tribal governance, or self-determination, is not conceptualised as discriminatory even if it is a privilege that no other United States citizen, or group of citizens, enjoys. ${ }^{37}$

Similarly, treaties between American Indian tribes and the federal government are interpreted contra proferentem in favour of the American Indian tribe in question and on the premise that tribes retain all the rights of a sovereign that are not expressly taken away under the Treaty. ${ }^{38}$ The treaties have the status of supreme law in the United States and thus override conflicting state law. ${ }^{39}$

Similarly to the logic of McHugh's point about Treaty rights vesting in Māori as political units rather than a racial monolith, the foundational Morton $v$ Mancari Supreme Court decision found that employment preferences for American Indians did not violate the Constitutional prohibition against invidious racial discrimination. ${ }^{40}$ The different treatment of Indians was based on their unique political and legal status as nations, taking into account historical and contextual factors, and thus was not a racial distinction. As Clinton, Goldberg and Tsosie note, "[1]egislation that relates to "Indian land, tribal status, self-government or culture" will not violate equal protection principles under the United States Constitution because, then citing United States $v$ Antelope, ${ }^{41}$ "such

35 See, for example, Cherokee Nation v Georgia 30 US (5 Pet) 1 (1831) and Worcester v Georgia 31 US (6 Pet) 515 (1832).

36 Indian Civil Rights Act of 196825 USC 1301-03 and Safe Drinking Water Act 42 USC 300.

37 Joseph seems to gloss over the US' law on the sui generis rights of American Indians in his paper despite drawing from US jurisprudence on equality. Joseph above n 21 .

38 US v Winans (1905) 198 US 371.

39 Washington v Washington State Commercial Passenger Fishing Vessel Association (1979) 443 US 658.

40 Morton v Mancari (1974) 417 US 535.

41 United States v Antelope (1977) 430 US 641. 
regulation is rooted in the unique status of Indians as a 'separate people' with their own political institutions." 42 Further, as such Indians "have a right to expect some special protection for their land, political institutions ... and culture". 43

Similarly, as was seen vividly in Washington $v$ Washington State Commercial Passenger Fishing Vessel Association (Washington), ${ }^{44}$ the US Supreme Court has this to say about a lowercourt ruling that treaties between Amercian Indians and the federal Government violate equal protection principles:

The Washington Supreme Court held that treaties would violate equal protection principles if they provided fishing rights to Indians that were not also available to non-Indians. The simplest answer to this argument is that this Court has already held that these treaties confer enforceable special benefits on signatory Indian tribes ... and has repeatedly held that the peculiar semisovereign and constitutionally recognized status of Indians justifies special treatment on their behalf when rationally connected to the Government's "unique obligation" toward the Indians.

In that case, the US Supreme Court awarded approximately 50\% of precious Washington State fisheries in areas covered by the Treaty to the Indian nations party to the relevant treaty protecting their fishing rights off-reservation. This was even though, at that time, over 6,600 non-treaty fishermen and only about 800 Indians made their livelihood from commercial fishing in the state of Washington.

As noted by McHugh and discussed above, the Treaty of Waitangi explicitly guarantees hapu, chiefs and individuals - not a racial group - political power. Just because New Zealand has adopted a rather strict version of parliamentary sovereignty that does not tolerate any competing sovereign power, unlike the US, does not mean there is any lesser justification for recognition of Māori political rights, including the Māori seats, or that they are racially discriminatory in the New Zealand context but not in the US. Moreover, we see that, to the extent that New Zealand does recognise Māori political rights, it does so in a very soft way, far from models that recognise degrees of Indigenous peoples' autonomy or self-government. ${ }^{45}$

42 Robert Clinton, Caroll Goldberg and Rebecca Tsosie American Indian Law: Native Nations and the Federal System (LexisNexis, US, 2007) 202.

43 Ibid.

44 Washington v Washington State Commercial Passenger Fishing Vessel Association (Washington) (1979) 443 US 658.

45 For an interesting discussion of various models of recognising "nations without states" see Montserrat Guibernau "Nations Without States: Political Communities in the Global Age" (2004) 25 Mich J Int'l L 1251 . 
The Canadian Constitution protects aboriginal and treaty rights, ${ }^{46}$ meaning they trump federal and provincial legislation, and, furthermore, section 25 insulates aboriginal and treaty rights from challenge under the Canadian Charter of Rights and Freedoms. This means that aboriginal and treaty rights cannot be reviewed for violating guarantees to freedom from racial discrimination. Like the US, Canada has a policy of recognising Indigenous peoples' self-government, negotiating in a number of instances for First Nations' jurisdiction over their territories, and the courts recognise the potential for self-governance rights to be proved under common law aboriginal rights jurisprudence. ${ }^{47}$ First Nations' exercise of jurisdiction over their territories has withstood review even in circumstances where non-First Nations Canadian citizens living on those territories are subject to First Nations laws but have no right to vote for the First Nations law-making entity. ${ }^{48}$

Even Australian legislative measures to recognise large areas of land belonging to Aboriginal groups, over which those groups prohibit access, have withstood claims of racial discrimination. The High Court found that such legislative measures constituted legitimate special measures and thus could not be struck down for inconsistency with Australia's Commonwealth laws prohibiting racial discrimination. ${ }^{49}$

In South Africa, the value of equality is especially important in the aftermath of apartheid. Article 1 of the Constitution states that it is "founded on ... human dignity, the achievement or equality and advancement of human rights and freedoms." Yet, the same Constitution expressly recognises African customary law and requires that it be applied, when applicable. ${ }^{50}$ As such, the African Constitution supports the view that equality requires that different groups be regulated, at least to some extent, by their own laws and not that of the dominant majority. As Zimmerman points out, in relation to South Africa's legal order: "[e]qual recognition of customary law in effect stands for equal political recognition of African people." 51

Internationally, both the UN Committee on the Elimination of Racial Discrimination (CERD Committee) and the General Assembly support the view that Indigenous peoples' rights do not discriminate against non-Indigenous peoples. Indeed, the adoption of a UN declaration recognising strong political, land, cultural and social rights, including the right to self-determination, by 144 states, with only four votes against (including New Zealand, and Australia has now reversed its

46 Section 35 of the Canadian Constitution.

47 For example $R v$ Pamajewon [1996] 2 SCR 221.

48 For example, see Campbell v British Columbia 189 DLR $\left(4^{\text {th }}\right) 333$.

49 Gerhady v Brown 57 ALR 472 (SCSA).

50 See Chapter 12 of the South African Constitution.

51 J Zimmerman "The Reconstruction of Customary Law in South Africa: Method and Discourse" Harv Blackletter LJ Spring 2001 197, 205. 
position), illustrates the collective wisdom world wide that Indigenous peoples' rights are required to achieve equality. ${ }^{52}$ Specifically, Article 19 requires states to provide for strong political rights for Indigenous peoples, stating:

States shall consult and cooperate in good faith with the indigenous peoples concerned through their own representative institutions in order to obtain their free, prior and informed consent before adopting and implementing legislative or administrative measures that may affect them.

The justifications for the Declaration on the Rights of Indigenous Peoples, reflected in the preambular provisions, include some of the contextual factors mentioned above, for example the injustices inflicted upon Indigenous peoples during European colonial expansion. ${ }^{53}$ Nor is the Declaration an isolated example of international recognition of Indigenous peoples' unique political rights. The final outcome document of the 2009 Review of the Durban Conference Against Racism World Conference includes recognition of Indigenous peoples' political rights. ${ }^{54}$

Similarly, the CERD Committee's General Recommendation on Indigenous Peoples requires states to respect Indigenous peoples' rights to further the goal of freedom from racial discrimination. ${ }^{55}$ Moreover, when considering New Zealand's state report in 2007, the CERD Committee noted that measures specifically directed towards Māori should not even be framed as "special measures" because such measures are only justified for as long as is necessary to attain equality for disadvantaged groups. In contrast, Indigenous peoples' rights are permanent, it stated, and are thus required for reasons above and beyond simply achieving parity between citizens. ${ }^{56}$

52 UN General Assembly Resolution 61/295 (13 September 2009).

53 Including: "Affirming that indigenous peoples are equal to all other peoples, while recognizing the right of all peoples to be different, to consider themselves different, and to be respected as such"; Affirming further that all doctrines, policies and practices based on or advocating superiority of peoples or individuals on the basis of national origin or racial, religious, ethnic or cultural differences are racist, scientifically false, legally invalid, morally condemnable and socially unjust"; "Reaffirming that indigenous peoples, in the exercise of their rights, should be free from discrimination of any kind"; "Concerned that indigenous peoples have suffered from historic injustices as a result of, inter alia, their colonization and dispossession of their lands, territories and resources, thus preventing them from exercising, in particular, their right to development in accordance with their own needs and interests."

54 Outcome Document of the Durban Review Conference (21 April 2009).

55 UN Committee on the Elimination of Racial Discrimination "General Recommendation XXIII: Indigenous Peoples" (18 August 1997) A/52/18, annex V.

56 Stating "[t]he Committee draws the attention of the State party to the distinction to be drawn between special and temporary measures for the advancement of ethnic groups on the one hand and permanent rights of indigenous peoples on the other hand." UN Committee on the Elimination of Racial Discrimination "Concluding Observations: New Zealand" (15 August 2007) UN Doc CERD/C/NZL/CO/17. See, also, informal records of the discussion between the CERD Committee and the New Zealand delegation in August 2007, on file with the author. 
Measures that extinguish Māori property rights, yet retain non-Māori property rights, constitute discrimination according to the CERD Committee as was seen in its decision on the FSA.

Unlike the "one-law-for-all" view heard in New Zealand's political domain, the CERD Committee's General Recommendation 14 notes that a distinction will not constitute discrimination where "the criteria for such differentiation judged against the objectives and purposes of the Convention are legitimate". 57

Catherine Iorns-Magallanes notes, with particular relevance when considering the legitimacy of the Māori seats, that: ${ }^{58}$

the international principles of political participation under democracy (including decentralisation) and cultural pluralism have resulted in an acceptance that indigenous peoples are entitled to 'spheres' of governmental or administrative autonomy for their communities as well as effective participation and consultation on all decisions affecting them that are nor appropriated by the larger institutions of government.

\section{THEORETICAL PERSPECTIVES}

The third principal argument in this paper is that bald statements that Māori rights discriminate appear unreflective and crude if they gloss over discourse on equality or are not accompanied with convincing or robust analysis. As the above discussion hopefully illustrates, equality is an intellectually challenging topic and interpretations of it have moved far beyond a simple assessment of distinctions in treatment of different groups.

Indeed, more inclusive and broad-ranging discourse about equality is essential in, and perhaps even a premise of, Western-styled democratic governments such as New Zealand's. ${ }^{59}$ One of the most important reasons is, as succinctly expressed by Cass Sunstein, "[greater] deliberation will

57 UN Committee on the Elimination of Racial Discrimination "General Recommendation XIV: Definition of Discrimination" (22 March 1993) A/48/18, para 2.

58 Catherine Iorns-Magallanes "International Human Rights and Domestic Law" P Havemann (ed) Indigenous Peoples' Rights in Australia, Canada and New Zealand (Oxford University Press, Oxford, 1999) 254.

59 Exceptions to the claim that New Zealand's academic dialogue is unreflective include Edward T Durie in "Justice, Biculturalism and Politics of Law" in M Wilson and A Yeatman (eds) Justice and Identity (Bridget Williams Books, Wellington, 1995); Mason Durie "The Treaty of Waitangi, Equality of Citizenship and Indigeneity" (Address to the Human Rights Commission Workshop on the Relationship between the Treaty of Waitangi and Human Rights, Wellington, 8 July 2003); Robert Joseph "Comparatively Speaking: A Summary for Objective 2" (Laws and Institutions for Aotearoa/New Zealand, Te Maataahauraki Research Institute, University of Waikato, February 2001); Paul McHugh, above n 32; Matthew Palmer The Treaty of Waitangi in New Zealand's Law and Constitution (Victoria University of Wellington Press, Wellington, 2008); Nicole Roughan, above n 5, and Andrew Sharp Justice and the Maori: the Philosophy and Practice of Maori claims in New Zealand since the 1970s (2 ed, Auckland, Oxford University Press, 1996). 
result in wiser judgements and better outcomes." 60 It is a view that was advanced by Aristotle. ${ }^{61}$ Waldron, with John Stuart Mill's help, concludes that "[s]imple truths, self-evident truths may form in simple minds, but complicated truths ... emerge, in Mill's words, only 'by the rough process of struggle between combatants fighting under hostile banners."'62

Relatively contemporary legal commentary on equality and multiculturalism, oftentimes liberal in genesis and emanating from Canada and the United States, is of particular relevance to New Zealand due to New Zealand's multicultural make-up and its liberal democratic values. Canada and New Zealand also share a similar colonial history and the adoption of peculiarly English-derived constitutional principles.

Marion Iris Young, ${ }^{63}$ Will Kymlicka, ${ }^{64}$ Arend Lijphart, ${ }^{65}$ Patrick Macklem, ${ }^{66}$ Ayelet Schacher, ${ }^{67}$ Charles Taylor ${ }^{68}$ and James Tully, ${ }^{69}$ amongst others, analyse the bias inherent in democracies where the institutional and political structure(s) reflects the values (political, cultural and social) of the majority, discussed above, although from different, and sometimes conflicting,

60 Cass Sunstein "Group Judgments: Deliberation, Statistical Means, and Information Markets" U Chicago Law \& Economics, Olin Working Paper No 219; U Chicago Public Law Working Paper No 72 (University of Chicago, Chicago, 2004) 2.

61 Aristotle wrote "the many, of whom each individual is not a good man, when they meet together may be better that the few good, if regarded not individually but collectively." In Stephen Everson (ed) The Politics (Cambridge University Press, Cambridge, 1988) Bk III Ch 11 1281b, as cited in Jeremy Waldron Law and Disagreement (Oxford University Press, Oxford, 1999) 72.

62 Law and Disagreement above n 61, 227, citing John Stuart Mill On Liberty (Bobbs Merril, Indianapolis, 1955) $\mathrm{Ch} 2,58$.

63 Iris Marion Young "Polity and Group Difference: A Critique of the Ideal of Universal Citizenship" (1989) 99 Ethics 250.

64 Will Kymlicka Multicultural Citizenship: A Liberal Theory of Minority Rights (Clarendon Press, Oxford, 1995).

65 Arend Lijphart "Back to Democratic Basics: Who Really Practices Majority Rule?" in Alex Hadenuis (ed) Nobel Symposium No 931007.

66 Indigenous Difference and the Constitution of Canada (University of Toronto Press, Toronto, 2001).

67 Ayelet Shachar "Two Critiques of Multiculturalism" 23 Cardozo L Rev 253, 281.

68 Charles Taylor The Ethics of Authenticity (Harvard University Press, Cambridge MA, 1991).

69 James Tully Strange Multiplicity: Constitutionalism in an Age of Diversity (Cambridge University Press, Cambridge, 1995) 
premises. ${ }^{70}$ They are concerned that the laws and institutions of liberal democracies speak the language, literally and metaphorically, of the dominant group in society. Kymlicka writes: ${ }^{71}$

A multicultural state which accords universal rights to all its citizens, regardless of group membership,

may appear to be neutral between various national groups. But in fact it can (and often does) systematically privilege the majority nation in certain fundamental ways. All of these decisions can dramatically reduce the ... cultural viability of a national minority, while enhancing that of the majority culture.

All of the above theorists advocate for the removal of the negative impacts of the democratic political bias against marginalised groups, although differing in their suggestions as to the appropriate means to achieve this.

Kymlicka argues for state recognition of models of autonomy and self-governance for Indigenous peoples. ${ }^{72} \mathrm{He}$ writes that it is not enough for the state to respond to claims for greater autonomy with "benign neglect", where a state does not support nor undermine "the freedom of people to express their particular cultural attachments." ${ }^{73} \mathrm{He}$ continues that the "usual process of majoritarian decision-making ... has been to render cultural minorities vulnerable to significant injustice at the hands of the majority, and exacerbates ethnocultural conflict." 74 Thus, autonomy is needed to insulate national minorities against such injustice. Durie shares this view to some extent, stating, "[i]t is, I hope, uncontroversial to consider that justice, in the broad sense of fairness, requires respect for all peoples - and for their laws. In many cases, therefore, a plural legal order may be necessary - with tribal courts, for example." 75

70 See also Duncan Ivison (ed) Political Theory and the Rights of Indigenous Peoples (Cambridge University Press, Cambridge, 2000).

71 Kymlicka above n 64, 52. Similarly, Shacher writes, that "for some people, some of the time, apparently neutral and impartial laws and public institutions are simply not enough to ensure that they enjoy a fair chance of inclusion in the body politic, as well as meaningful access to its goods, resources, and ultimately powers. ... Like it or not, cultural, religious, racial, ethnic, gender, sexual orientation, and other (chosen or unchosen) affiliations tend to make the achievement of the goals of freedom and equality more difficult for those who have not always in the past been treated as full members of the polity." See, also, Bhikhu Parekh Rethinking Multiculturalism: Cultural Diversity and Political Theory (Palgrave Macmillan, 2000) 16, as cited in Ayelet Shachar "Two Critiques of Multiculturalism" 23 Cardozo L Rev 253, 264.

72 Kymlicka writes "group differentiated self-government rights compensate for unequal circumstances which put the members of minority cultures at a systemic disadvantage in the cultural market place, regardless of their personal choices in life." Ibid, 113.

73 Ibid, 3.

74 Ibid, 5.

75 E T Durie "Justice, Biculturalism and the Politics of Law" in M Wilson and A Yeatman (eds) Justice and Identity (Bridget Williams Books, Wellington, 1995) 33-34. Robert Joseph also states, when writing about indigenous peoples in a number of nations including New Zealand, that "[t]he ultimate justice for 
Not unlike Kymlicka, Geertz argues that "any nations split into primordially defined groups" must discover a "form competent to contain the country's diversity." He goes on to argue that minority security is a common good - good for the majority as well as the minority - and "by designing a constitution to allay the fears of defenceless ethnic sub-groups, the framers of a regimefounding compromise can secure national cooperation necessary for economic prosperity ..."76

Tully argues that additional political measures are necessary for Indigenous peoples to remedy the systemic inequality, and injustice, that arises from the failure of Western states, and of Western ethno-centric liberal philosophy, to recognise Indigenous peoples' historical, pre-colonial political self-determination. ${ }^{77}$ Iris Marion Young maintains that inclusive political decision-making with mechanisms for "specific representation of marginalized social groups" is required. ${ }^{78}$ She emphasises the need for democratic processes that promote greater inclusion of minorities "as a means of promoting more just outcomes". ${ }^{79}$ She writes: ${ }^{80}$

One important way to promote greater inclusion of members of under-represented social groups is through political and associational institutions designed specifically to increase the representation of women, working-class people, racial or ethnic minorities, disadvantaged castes and so on.

Along similar lines, Arend Lijphart's 'political consociationalism' "provides formal and informal rules that can facilitate interethnic and intercommunal accommodation. The two most important elements are broad participation in decision-making by the representatives of the different ethniccommunal groups and cultural autonomy for those groups that wish to have it." ${ }^{81}$ In a similar vein,

indigenous and minority groups depends on political power sharing through constitutional reform. Accordingly, a plural political-legal order is necessary." Robert Joseph "Comparatively Speaking: A Summary Paper of Preliminary Principles and Aims." (Laws and Institutions for Aotearoa/New Zealand, Te Maataahauraki Research Institute, University of Waikato, February 2001) 1, University of Waikato http://lianz.waikato.ac.nz/publications-working.htm (accessed 11 June 2009).

76 C Geertz The Interpretation of Cultures (Basic Books, New York, 1973) 309.

77 For his critique of Locke in particular, see James Tully "The Crisis of Identification: The Case of Canada" (2006) 42 Political Studies 77. See also Mark Bennett "Indigeneity as Self-Determination" (2005) 4 Indigenous Law Journal 75.

78 Iris Marion Young Inclusion and Democracy (Oxford University Press, New York, 2000) 8. See also the discussion of Marion Young in "Te Tiriti and the Constitution: Rethinking Citizenship, Justice, Equality and Democracy" (2005) 3 NZJPIL 285.

79 Inclusion and Democracy, ibid, 17.

80 Ibid, 141

81 Lijphart, above n 65. As described by Russell A Miller "Self-Determination in International Law and the Demise of Democracy" (2003) 41 Colum J Transnat'l L 601, 642 - 643. See, also, the discussion in Steven Wheatley Democracy, Minorities and International Law (Cambridge University Press, Cambridge, 2005), who maintains that the Lijbhart theory is not supported by international law. 
Guibernau suggests that the "one person, one vote, one value" view, expressed by Joseph, ignores the potential of different vote values to deepen, rather than undermine, democracy by giving voice to minority or otherwise marginalised groups. ${ }^{82}$

From a more international legal perspective, Jan Klabbers argues that the right to selfdetermination, of which Indigenous peoples are beneficiaries as a matter of international law, includes the right to political participation. ${ }^{83}$

Now that self-determination can no longer simply be construed as a right of colonies to independent, it has been turned into a right of peoples to take part in decisions affecting their future. ... [S]elfdetermination is best understood as a procedural right: entities have a right to see their position taken into account whenever their future is being decided. ... [It is] a right to be taken seriously.

Somewhat ironically, and to differing degrees, many of abovementioned authors utilise nonIndigenous, Western liberal theory to justify exceptional measures to guarantee equal Indigenous political voice in a post-colonial democracy. Their goal is pragmatic. Kymlicka has commented:

For better or worse, it is predominantly non-aboriginal judges and politicians who have the ultimate power to protect and enforce aboriginal rights, and so it is important to find a justification of them that such people can understand. Aboriginal people may have their own understanding of self-government drawn from their own experience, and that is important. But it is also important, politically, to know how non-aboriginal peoples ... will relate them to their own experiences and traditions ... Aboriginal rights, at least in their robust form, will only be secure when they are viewed, not as competing with liberalism, but as an essential component of liberal political practice. ${ }^{84}$

In saying that, there are also those, such as Taiakake Alfred, who reject the liberalism inherent in the multiculturalist viewpoint. ${ }^{85}$ From his perspective, Indigenous peoples must reject the continuing colonial influence of non-Indigenous political philosophies, even if they can be employed to argue for greater autonomy for Indigenous peoples, to practice and assert their own. He writes that the: ${ }^{86}$

lack of any coherent strategy to solve [obvious injustices and misuses of power, and the absence of traditional values] suggests that Native people need to go beyond the divisive electoral politics and

82 See Guibernau, above n 45

83 Jan Klabbers The Right to be Taken Seriously: Self-Determination in International Law www.helsinki.fi/eci/Publications/JKYOGJA.pdf 4 (accessed 20 April 2009).

84 Will Kymlicka, Liberalism, Community, and Culture (Oxford: Clarendon Press, 1989) as quoted in Mark Bennett "Indigeneity as Self-Determination" (2005) 4 Indigenous Law Journal 75, 87.

85 Taiaiake Alfred Peace, Power and Righteousness: An Indigenous Manifesto (2 ed, Oxford, Oxford University Press, 2008).

86 Ibid, 4-5 
Western-style institutions recommended by most scholars and develop solutions for themselves from within their own cultural frameworks, reuniting themselves as individuals with their collectivity. ... By ignoring traditional teachings, Native people risk losing what they most need to survive as indigenous peoples, and move closer still to the cultural vortex of the other, foreign, collectivity.

On the other side of the spectrum, Brian Barry rejects cultural justifications for different treatment under political and legal structure. He is of the view that the state should not intervene in the private realm, which includes culture. ${ }^{87} \mathrm{He}$ also suggests that taking culture into account in political and legal decision-making will exacerbate difference, which is not desirable.

Waldron, like Barry, is less convinced by justifications for difference based on culture, seeing attachment to cultural values as a matter of choice. ${ }^{88} \mathrm{He}$ is cosmopolitan in outlook. ${ }^{89}$ Nonetheless, he has also recognised the cultural bias in liberal legal systems, pointing out that a policy behind legislation can be culturally biased and, as a result, have a disproportionately negative impact on people belonging to a minority culture. He states: ${ }^{90}$

For it looks now as though the Diceyan formulation - "every man, whatever be his rank or condition is subject to the ordinary law of the realm" - is already a preference for the rule of one kind of law over another. Among all the competitors, state law is evidently the only law that has a chance of being uniform across the whole society (by which I mean the whole society governed by the state, and everyone in it.) ... so the rule of law aspiration, "one law for all" ... is the inherent ally of state law, rather than an independent consideration that helps settle the issue between state law and its cultural competitors.

\section{CONCLUSION}

The overriding point of this paper is this: political dialogue in New Zealand on the rights of Indigenous peoples and racial discrimination ought to engage with New Zealand's colonial and Constitutional context, with its biases against Māori, comparative and international jurisprudence, and also contemporary political and legal theory. It is shallow to claim that Māori rights discriminate against non-Māori without greater attention to the justifications for those rights. Moreover, there is a danger that, without a better quality of debate on these issues, Māori will be further discriminated against and feel even less attached to New Zealand citizenship. As Roughan points out, "where States are home to multiple national groups, attempts at integration or

87 Brian Barry Culture and Equality: an Egalitarian Critique of Multiculturalism (Polity Press in association with Blackwell Publishers, Cambridge, 2001).

88 See Jeremy Waldron "Minority Cultures and the Cosmopolitan Alternative" in Will Kymlicka and Walter Norman Citizenship in Diverse Societies (Oxford, Oxford University Press, 1995) 93, 100.

89 Ibid, 93.

90 Waldron, above n 4, 17. 
assimilation of minority or indigenous nations have more often led to stronger affirmations of distinct identities". ${ }^{91}$

91 Nicole Roughan and referencing Roger Maaka and Augie Fleras "Engaging with Indigeneity: Tino Rangatiratanga in Aotearoa" in Duncan Ivison, Paul Patton and Will Sanders (eds) Political Theory and the Rights of Indigenous Peoples (Cambridge University Press, Cambridge, 2000) 93. 